\title{
LIPOPOLYSACCHARIDES OF IRON-OXIDIZING LEPTOSPIRILLUM FERROOXIDANS AND THIOBACILLUS FERROOXIDANS
}

\author{
AKIRA YOKOTA, YORIKO YAMADA, AND KO IMAI \\ Institute for Fermentation, Osaka, 17-85, Juso-honmachi 2-chome, \\ Yodogawa-ku, Osaka 532, Japan
}

(Received October 19, 1987)

\begin{abstract}
Lipopolysaccharides were isolated from one strain of Leptospirillum ferrooxidans and three strains of Thiobacillus ferrooxidans. All strains contained 2-keto-3-deoxyoctonate (KDO), heptose(s) and glucosamine besides neutral sugars, but were devoid of phosphorus. Lipopolysaccharides from iron-grown cells and from sulfur-grown cells had a similar chemical composition. Thus, the chemical properties of the lipopolysaccharide was unaffected by the energy source utilized.

Chemical analysis of lipopolysaccharide from Thiobacillus ferrooxidans IFO 14262 revealed the presence of L-rhamnose, D-glucose, L-glycero-Dmanno-heptose, KDO, D-glucosamine, and a lipophilic sugar identified as L-acofriose (3-O-methyl-L-rhamnose). 3-Hydroxymyristic acid was the main fatty acid. By hydrolysis in weak acid, the lipopolysaccharide has been separated into the polysaccharide part ("degraded polysaccharide") and lipid A. Presumably the lipid A contains a glucosamine backbone.
\end{abstract}

The chemical composition of lipopolysaccharides (LPSs) isolated from ironoxidizing bacteria was studied by WANG et al. (1), VeSTAL et al. (2), and HIRT and VeSTAL (3). According to the latter two reports, LPSs isolated from Thiobacillus ferrooxidans strain TM grown on ferrous sulfate or on glucose were similar in chemical composition but differed from that of LPS grown on elemental sulfur in the content of hexosamine, KDO, and heptoses and in the composition of fatty acis. However, it was pointed out that cultures of many iron-oxidizing bacteria contained contaminants of acidophilic chemoorganotrophs, such as Acidiphilium cryptum (4)

Abbreviations used in this text are as follows: GLC, gas-liquid chromatography; HPLC, highperformance liquid chromatography; KDO, 2-keto-3-deoxyoctonate; LPS, lipopolysaccharide; PAGE, polyacrylamide gel electrophoresis; PC, paper chromatography; SDS, sodium dodesyl sulfate; TLC, thin-layer chromatography.

Address reprint requests to: Dr. A. Yokota, Institute for Fermentation, Osaka, 17-85, Jusohonmachi 2-chome, Yodogawa-ku, Osaka 532, Japan. 
and Acidiphilium sp.(5), or of a heterotrophic chemolithotroph, Thiobacillus acidophilus (1,5-10). GUAY and SILVER isolated T. acidophilus as a contaminant from the culture of $T$. ferrooxidans strain TM (6). Therefore, little is known about the chemical composition of LPS isolated from pure cultures of iron-oxidizing bacteria. Very recently, RODRIGUEZ et al. (II) reported on the chemical composition of the LPS of $T$. ferrooxidans strain $\mathrm{R}_{2}$ grown on ferrous sulfate.

A systematic study of a large collection of mesophilic iron-oxidizing bacteria made by HARRISON (12) demonstrated that these bacteria comprise seven different DNA homology groups. To determine the intra- and inter-specific diversity in the chemical composition of the LPS of iron-oxidizing bacteria, we obtained four strains from HARRISON's laboratory and examined the sugar composition. We also report the characterization of the LPS from T. ferrooxidans IFO 14262.

\section{MATERIALS AND METHODS}

Bacterial strains and cultural conditions. Strains of iron-oxidizing bacteria, Leptospirillum ferrooxidans IFO 14244 ( = strain BU-1, formerly named Thiobacillus ferrooxidans but later identified as L. ferrooxidans from its cell morphology and lack of sulfur utilization as a source of energy) $(10,12)$, Thiobacillus ferrooxidans IFO 14245 (=strain Lp)(12), IFO 14246 (=strain BA-4)(12) and IFO 14262 (=strain PH) (12) were obtained from Dr. HARRISON (Missouri University, U.S.A.). They were cultured in a medium containing: $\left(\mathrm{NH}_{4}\right)_{2} \mathrm{SO}_{4}, 2 \mathrm{~g} ; \mathrm{K}_{2} \mathrm{HPO}_{4}, 0.5 \mathrm{~g} ; \mathrm{KCl}, 0.1 \mathrm{~g}$; $\mathrm{MgSO}_{4} \cdot 7 \mathrm{H}_{2} \mathrm{O}, 0.5 \mathrm{~g} ; \mathrm{ZnSO}_{4} \cdot 7 \mathrm{H}_{2} \mathrm{O}, 0.01 \mathrm{~g} ; \mathrm{Ca}\left(\mathrm{NO}_{3}\right)_{2}, 0.01 \mathrm{~g} ; \mathrm{NiSO}_{4} \cdot 6 \mathrm{H}_{2} \mathrm{O}, 0.01 \mathrm{~g}$; $\mathrm{FeSO}_{4} \cdot 7 \mathrm{H}_{2} \mathrm{O}, 40 \mathrm{~g}$ or powdered sulfur, $5 \mathrm{~g}$; and distilled water, $1000 \mathrm{ml}(12)$. The $\mathrm{pH}$ was adjusted to 3.5 with $2 \mathrm{~N} \mathrm{H}_{2} \mathrm{SO}_{4}$. The culture broth $(330 \mathrm{ml})$ in a $1-l$ Erlenmeyer flask was incubated at $28^{\circ} \mathrm{C}$ for $5-14$ days on a rotary shaker. The cells were harvested by centrifugation, and washed with distilled water.

Isolation and purification of LPS. LPS was extracted by the hot-phenol method of WestPhaL and JANN (13), and purified by centrifugation at 140,000 $\times g$ for $3 \mathrm{~h}$ in a Beckman U-2 ultracentrifuge.

To identify L-acofriose in the LPS of $T$. ferrooxidans, LPS was isolated from the cells obtained from $50 l$ of culture broth. The LPS obtained $(195 \mathrm{mg})$ was then hydrolyzed in $2 \mathrm{M} \mathrm{HCl}$ at $100^{\circ} \mathrm{C}$ for $2 \mathrm{~h}$. After the precipitate was removed by centrifugation, $\mathrm{HCl}$ was removed by evaporation in vacuo. The residue was chromatographed on a column of cellulose powder $(2.2 \times 75 \mathrm{~cm})$ with solvent B (see Analytical methods). Fractions containing L-acofriose (No. 125-165) were combined and concentrated in vacuo.

Analytical methods. Neutral sugars were liberated by $2 \mathrm{M} \mathrm{HCl}$ at $100^{\circ} \mathrm{C}$ for $2 \mathrm{~h}$. $\mathrm{HCl}$ was removed by repeated evaporation in vacuo. Descending paper chromatography (PC) (Toyo filter paper No. 50) and thin-layer chromatography (TLC) (cellulose-TLC, precoated and silica gel 60-TLC, precoated) were carried out using the following solvent systems: (A) n-butanol-pyridine-water $(40: 11: 6$, $\mathrm{v} / \mathrm{v} / \mathrm{v})$, (B) $n$-butanol-pyridine-water-acetate $(60: 40: 30: 3, \mathrm{v} / \mathrm{v} / \mathrm{v} / \mathrm{v})$, (C) $n$-butyl 
acetate-pyridine-ethanol-water $(8: 2: 2: 1, \mathrm{v} / \mathrm{v} / \mathrm{v} / \mathrm{v})$. Sugar spots were detected by spraying the chromatograms with anilinium hydrogen phthalate and alkaline silver nitrate for PC and cellulose-TLC, and with $50 \%$ hydrogen sulfate for silica gel TLC. High-performance liquid chromatography (HPLC) was performed on a Shimadzu Model LC-5A pumping system, using a Shim-pack ISA-07/S2504 $(4.0 \times 250 \mathrm{~mm})$ column according to the method described by Mikami and IsHida(14). Fluorescence intensities of the effluent were measured with a Shimadzu Model RF530 spectrofluorometer and a Chromatopac.

To quantitatively determine neutral sugars, the LPS was hydrolyzed in $0.1 \mathrm{M}$ $\mathrm{HCl}$ at $100^{\circ} \mathrm{C}$ for $48 \mathrm{~h}$. The sugars were converted into alditol acetates (15) and were analyzed by gas-liquid chromatography (GLC) on a glass column $(0.26 \times 100 \mathrm{~cm})$ with Advance DS (Shimadzu) at a column temperature of $160-225^{\circ} \mathrm{C}\left(3^{\circ} \mathrm{C} / \mathrm{min}\right)$ and a helium gas flow of $50 \mathrm{ml} / \mathrm{min}$.

Aminohexoses were liberated by $4 \mathrm{M} \mathrm{HCl}$ at $100^{\circ} \mathrm{C}$ for $6 \mathrm{~h}$. $\mathrm{HCl}$ was removed by repeated evaporation in vacuo. The sugars were analyzed by cellulose-TLC and quantified in an amino acid analyzer, Hitachi model 838.

To detect $\mathrm{KDO}$, LPS was hydrolyzed in $0.1 \mathrm{M} \mathrm{H}_{2} \mathrm{SO}_{4}$ at $100^{\circ} \mathrm{C}$ for $10 \mathrm{~min}$, neutralized with a saturated solution of $\mathrm{Ba}(\mathrm{OH})_{2}$, and concentrated by evaporation in vacuo. KDO was determined by the method of WeissBach and Hurwitz (16). Fatty acids were released from LPS by hydrolysis in $4 \mathrm{M} \mathrm{HCl}$ at $100^{\circ} \mathrm{C}$ for $6 \mathrm{~h}$. Fatty acids, extracted with petroleum ether $\left(30\right.$ to $\left.60^{\circ} \mathrm{C}\right)$, were weighed and esterified with $5 \%$ methanolic $\mathrm{HCl}$ at $100^{\circ} \mathrm{C}$ for $2 \mathrm{~h}$. A chloroform solution of the fatty acids methyl ester was analyzed by GLC on a glass column $(0.26 \times 200 \mathrm{~cm})$ of diethylene glycol succinate polyester ( $5 \%$ on Chromosorb W, 60 to 80 mesh) at a column temperature of $165^{\circ} \mathrm{C}$, or alternatively with a glass column of OV-1 $(3 \%$ on Chromosorb W, 60 to 80 mesh) at a column temperature of $180^{\circ} \mathrm{C}$.

Phosphorus was determined by the method of CHEN et al. (17).

Demethylation of L-acofriose. The sugar ( $1 \mathrm{mg}$ ) was suspended in $1 \mathrm{ml}$ of $\mathrm{BCl}_{3}$ in $\mathrm{CH}_{2} \mathrm{Cl}_{2}$ and placed open in a closed dry dessicator for $18 \mathrm{~h}(18)$. Boron was removed by several evaporations with methanol. The residue was dissolved in water and passed through a small column of IR $120\left(\mathrm{H}^{+}\right)$and the sugars were examined by HPLC, TLC and by GLC as the alditol acetates.

Degradation of LPS. LPS was treated with $1 \%$ acetic acid at $100 \mathrm{C}$ for $2 \mathrm{~h}$. The water-insoluble moiety (lipid A) was separated by centrifugation at $4,000 \times g$ for $5 \mathrm{~min}$, washed with water and acetone, and lyophilized. Water-soluble moiety ("degraded polysaccharide") was further purified by Sephadex G-50 column $(1.8 \times 115 \mathrm{~cm})$ chromatography with a pyridine-acetic acid-water $(10: 4: 1,000$, $\mathrm{v} / \mathrm{v} / \mathrm{v}) \cdot$ buffer as eluant.

Sodium dodesyl sulfate-polyacrylamide gel electrophoresis (SDS-PAGE). A polyacrylamide gel was prepared and run with a buffer system of LAMMLI (19). The separating gel contained $15 \%$ acrylamide and $0.1 \%$ SDS, and the stacking gel $7.5 \%$ acrylamide and $0.1 \%$ SDS. LPS bands were visualized by silver staining as described by TSAI and FRASCH (20). 
Physical and chemical analyses. Optical rotations were measured with a Japan Spectroscopic DIP-181 polarimeter. ${ }^{1} \mathrm{H}-\mathrm{NMR}$ spectrum was measured with a Varian XL 100-A (100.1 MHz) spectrometer with tetramethylsilane as a reference. The electron impact mass spectra were measured with a Hitachi M-80A mass spectrometer and chemical ionization mass spectra were measured with a JMS-DX 300 mass spectrometer.

Chemicals. KDO and Salmonella typhimurium LPS were purchased from Sigma Chemical Co. (U.S.A.). 6-Deoxy-L-talose was prepared from the cell-wall of Microbacterium arborescens IFO $3750(21)$.

\section{RESULTS}

\section{Chemical composition of LPS from iron-oxidizing bacteria}

LPSs were obtained from all strains with yields of about 0.5 to $1.5 \%$. Neither ribose nor 2-deoxyribose was detected in the HPLC analyses of all LPSs studied, which is proof that they were almost free from contamination with nucleic acids. Since sufficient amounts of the purified LPSs were not available, with the exception of that from strain IFO 14262, the sugar composition was analyzed only qualitatively. The individual sugar components were examined by HPLC or GLC and chemical analyses. The results are summarized in Table 1.

Rhamnose, heptoses, KDO and glucosamine were found as common sugar components in the LPSs of all strains examined. The LPSs from strains IFO 14245, and IFO 14246 contained both D-glycero-D-manno-heptose and L-glycero-D-mannoheptose. As major neutral sugars besides rhamnose, strain IFO 14244 contained mannose, xylose, and an unknown sugar; strain IFO 14245 contained glucose and mannose; strain IFO 14246 contained glucose and xylose; and strain IFO 14262 contained glucose and L-acofriose. Phosphorus, an usual component of lipid A of gram-negative bacterial LPS, was virtually absent from the LPSs of all these strains. Identification of L-acofriose is described later.

\section{Influence of energy source on the chemical composition of LPS}

LPSs extracted from cells of strains IFO 14246 and IFO 14262 grown on iron or elemental sulfur showed no striking differences in chemical composition (Tables 1 and 2). These LPSs from strain IFO 14262 were also examined by SDS-PAGE and silver staining. Both LPSs showed a similar migration pattern (Fig. 1).

\section{LPS of T. ferrooxidans IFO 14262}

To determine the chemical composition of the LPS of $T$. ferrooxidans IFO 14262 and its polysaccharide and lipid A moieties in more detail, further studies were carried out.

Analyses for neutral sugars: The neutral sugar fraction obtained by acid hydrolysis of the LPS was analyzed by PC, TLC, HPLC, and GLC after the sugars were converted into their respective alditol acetates. Rhamnose, glucose, and a 
Table 1. Effect of energy source on sugar composition of LPS from cultures of iron-oxidizing bacteria.

\begin{tabular}{|c|c|c|c|c|c|c|c|c|c|c|c|c|c|}
\hline \multirow[b]{2}{*}{ Strain } & \multirow[b]{2}{*}{ 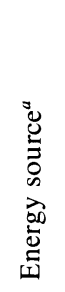 } & \multicolumn{8}{|c|}{ Neutral sugar composition ${ }^{b}$} & \multirow[b]{2}{*}{$\begin{array}{l}\stackrel{y}{0} \\
0 \\
\stackrel{0}{0} \\
\stackrel{0}{0} \\
\text { I }\end{array}$} & \multirow[b]{2}{*}{ ڤ̊ } & \multirow[b]{2}{*}{ 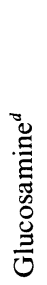 } & \multirow[b]{2}{*}{ 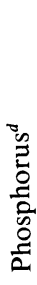 } \\
\hline & & 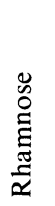 & $\begin{array}{l}\ddot{\mathscr{O}} \\
\stackrel{0}{\Xi} \\
\frac{\Xi}{0}\end{array}$ & 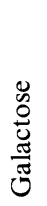 & 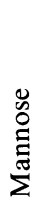 & 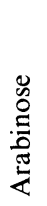 & $\frac{\ddot{\infty}}{\ddot{o}_{x}}$ & 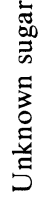 & 兽 & & & & \\
\hline $\begin{array}{l}\text { Leptospirillum } \\
\quad \text { ferrooxidans } \text { IFO } 14244\end{array}$ & $\mathrm{Fe}$ & 57 & $\mathrm{t}^{e}$ & $\mathrm{t}$ & 11 & $\mathrm{t}$ & 15 & 17 & - & LD & + & + & - \\
\hline $\begin{array}{l}\text { Thiobacillus } \\
\quad \text { ferrooxidans IFO } 14245\end{array}$ & $\mathrm{Fe}$ & 57 & 23 & - & 20 & - & - & - & - & $\mathrm{DD}+\mathrm{LD}$ & + & + & - \\
\hline Thiobacillus & $\mathrm{Fe}$ & 65 & 6 & - & - & $\mathrm{t}$ & 29 & - & - & $\mathrm{DD}+\mathrm{LD}$ & + & + & - \\
\hline ferrooxidans IFO 14246 & $\mathrm{~S}$ & 62 & 14 & - & - & $\mathrm{t}$ & 24 & - & - & $\mathrm{DD}+\mathrm{LD}$ & + & + & - \\
\hline Thiobacillus & $\mathrm{Fe}$ & 32 & 60 & - & - & - & - & - & 8 & LD & + & + & - \\
\hline ferrooxidans IFO 14262 & $\mathrm{~S}$ & 34 & 55 & - & - & - & - & - & 11 & LD & + & + & - \\
\hline
\end{tabular}

${ }^{a} \mathrm{Fe}$, cultured on ferrous sulfate medium; S, cultured on elemental sulfur medium.

$b$ Analyzed by HPLC and expressed as a percentage of the total sugar fraction.

c Examined by GLC and tentatively identified as D-glycero-D-manno-heptose (DD) and L-glycero-Dmanno-heptose (LD) from the retention times.

d Examined by chemical method, respectively.

e Trace amount.

Table 2. Chemical composition of the LPS from Thiobacillus ferrooxidans IFO 14262.

\begin{tabular}{|c|c|c|}
\hline \multirow{2}{*}{ Component } & \multicolumn{2}{|c|}{$\begin{array}{l}\text { Amount of component } \\
\text { (mg/100 mg of LPS) }\end{array}$} \\
\hline & Sulfur-grown & Fe-grown \\
\hline Total neutral sugars & 62.6 & 61.4 \\
\hline L-Acofriose & 12.7 & 11.3 \\
\hline L-Rhamnose & 25.0 & 23.6 \\
\hline D-Glucose & 24.6 & 25.8 \\
\hline L-Glycero-D-manno-heptose & 0.3 & 0.7 \\
\hline 2-Keto-3-deoxyoctonate & 0.12 & $\mathrm{ND}^{a}$ \\
\hline D-Glucosamine & 2.1 & $t^{b}$ \\
\hline Total fatty acids & 16.0 & + \\
\hline 3-OH-14:0 & $(80 \%)$ & ND \\
\hline $16: 0$ & $(4 \%)$ & ND \\
\hline $16: 1$ & $(10 \%)$ & ND \\
\hline $18: 0$ & $(3 \%)$ & ND \\
\hline $18: 1$ & $(3 \%)$ & ND \\
\hline Phosphorus & $<0.01$ & $<0.01$ \\
\hline
\end{tabular}

a Not determined.

$b$ Present but not quantified. 


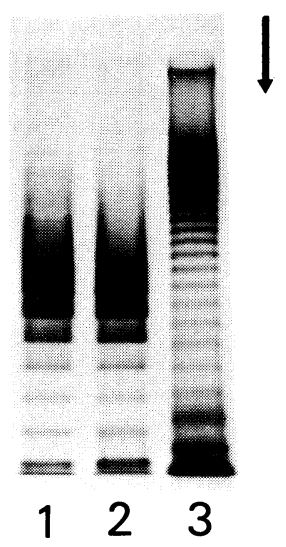

Fig. 1. Sodium dodesyl sulfate-polyacrylamide gel electrophoresis of the LPSs from iron-grown (1) and sulfur-grown (2) cells of Thiobacillus ferrooxidans IFO 14262 and from Salmonella typhimurium (3).

lipophilic sugar were present in large amounts; and a small amount of L-glycero-Dmanno-heptose was also present. The optical rotation of the isolated sugars, separated by PC, revealed an L-configuration for rhamnose and a D-configuration for glucose and glucosamine.

Isolation and characterization of L-acofriose: The lipophilic sugar, which was contained in the LPS, was stained with anilinium hydrogen phthalate but not with alkaline silver nitrate on PC. It was prepared from LPS hydrolysate by cellulose powder column chromatography. From $193 \mathrm{mg}$ of crude LPS, $12 \mathrm{mg}$ of L-acofriose was isolated as a syrup in pure form.

Chemical ionization mass spectrometric analysis of the sugar with ammonia as reactant gas (Fig. 2) showed the equasimolecular peaks $m / z 196\left(\mathrm{M}+\mathrm{NH}_{4}\right)$ and 178 $\left(\mathrm{M}+\mathrm{NH}_{4}-\mathrm{H}_{2} \mathrm{O}\right)$, which indicated the molecular weight of the sugar was 178 . The ${ }^{1} \mathrm{H}-\mathrm{NMR}$ spectrum of the sugar showed a doublet (total $3 \mathrm{H}$ ) at $\delta 1.30$ and a singlet (total $3 \mathrm{H}$ ) at $\delta 3.47$, which indicated that the sugar has one $\mathrm{C}$-methyl group and one O-methyl group.

From these results, the sugar could be assumed to be a mono O-methyled deoxyhexose. It was converted into its alditol acetate and analyzed with electron impact mass spectrometry (Fig. 3). Fragmentation at $20 \mathrm{eV}$ gave the following main fragments: $m / z 43,87,101,129,143,189$ and 203 . These fragments are typical for the fragmentation of 3-O-methyl ethers of 6-deoxyhexoses $(22,23)$.

The sugar was then converted into its parent 6-deoxyhexose by demethylation using the $\mathrm{BCl}_{3}$ technique of ALLEN et al.(18). The demethylated product was analyzed by TLC, HPLC, and GLC; it exhibited the same characteristics as Lrhamnose on the three chromatograms.

The sugar had $R_{\text {rha }} 1.82$ on PC in solvent C, consistent with identification as 3O-methylrhamnose (acofriose) (Table 3). It gave color reactions of 6-deoxyhexose 


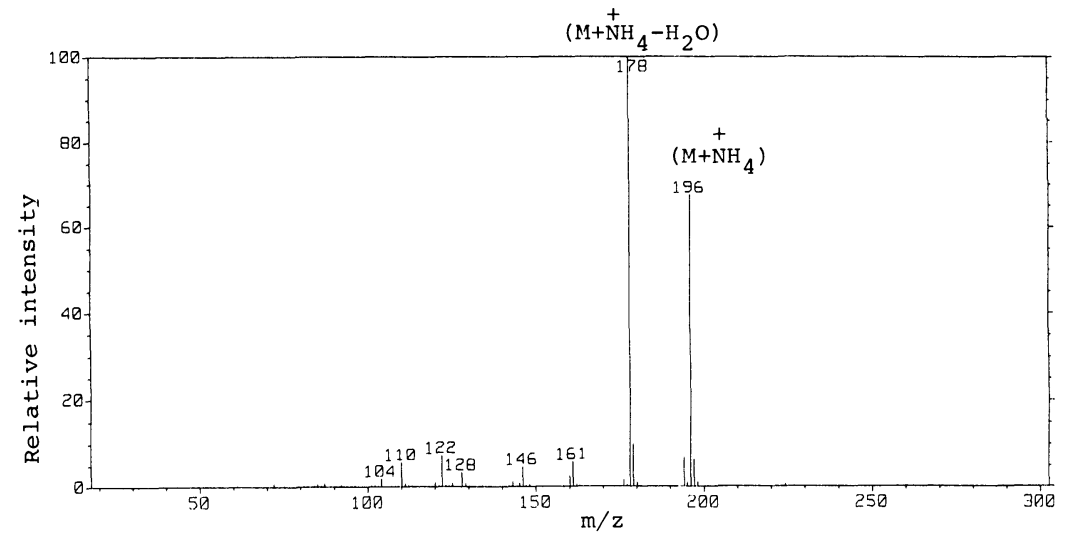

Fig. 2. Mass spectrum (chemical ionization mass spectrometry with ammonia) of Lacofriose.

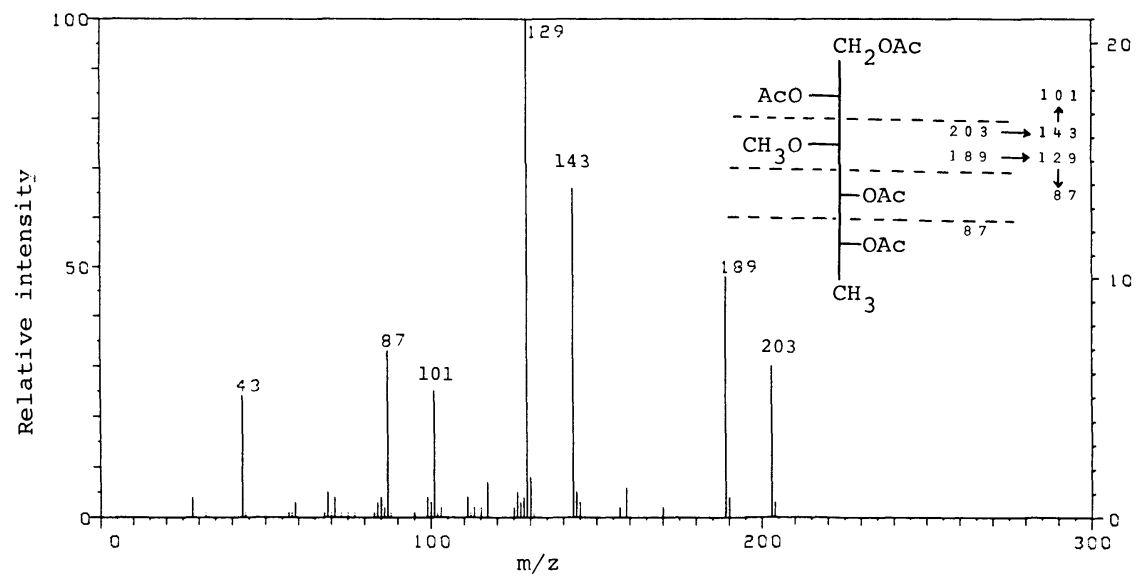

Fig. 3. Mass spectrum (electron impact mass spectrometry) and fragmentation scheme of alditol acetate of L-acofriose.

on PC with anilinium hydrogen phthalate and on TLC with hydrogen sulfate (Table $3)$.

The optical rotation of the 3-O-methyl-rhamnose was positive $\left([\alpha]_{D}+36^{\circ}\right.$ $(c=0.4$, water $)$ ) indicating that the sugar has an $\mathrm{L}$ configuration. Literature values of $L$-acofriose are $[\alpha]_{D}+30^{\circ} \sim+39.1^{\circ}(24,25)$ and for D-acofriose $[\alpha]_{D}-27^{\circ}(26)$.

Analyses for amino sugars, KDO and phosphorus: Separation of the acid hydrolysate of the LPS on an amino acid analyzer gave only a glucosamine peak, and no further amino sugars could be detected.

The assay for KDO in a mild hydrolysate of the LPS showed the presence of a small amount of KDO. The LPS was virtually free of phosphorus. 
Table 3. $R f$ values and color reactions on paper and thin-layer chromatograms of L-acofriose.

\begin{tabular}{|c|c|c|c|c|c|}
\hline & \multicolumn{2}{|c|}{$R f$ values on $\mathrm{PC}^{a}$} & \multicolumn{2}{|c|}{ Color reaction on $\mathrm{PC}$} & \multirow{2}{*}{$\begin{array}{c}\text { Color reaction } \\
\text { on TLC } \\
\left(50 \% \mathrm{H}_{2} \mathrm{SO}_{4}\right)\end{array}$} \\
\hline & $R_{\text {rha }}$ & $(\text { Reference })^{b}$ & $\begin{array}{l}\text { Alkaline } \\
\mathrm{AgNO}_{3}\end{array}$ & $\begin{array}{c}\text { Aniline } \\
\text { hydrogen phthalate }\end{array}$ & \\
\hline L-Rhamnose & 1.00 & $(1.00)$ & positive & positive & yellow \\
\hline 3-O-Methyl-D-fucose & - & $(1.30)$ & negative $^{c}$ & positive $^{c}$ & yellow ${ }^{d}$ \\
\hline 6-Deoxy-L-talose & 1.59 & $(1.55)$ & positive & positive & yellow \\
\hline 3-O-Methyl-L-rhamnose & - & $(1.80)$ & negative $^{c}$ & positive $^{c}$ & yellow ${ }^{d}$ \\
\hline L-Acofriose & 1.82 & & negative & positive & yellow \\
\hline
\end{tabular}

a Solvent $\mathrm{C}$.

$b$ From Ref. (34).

c From Ref. (30).

d From Ref. (35).

Table 4. Chemical composition of the lipid A and degraded polysaccharide of LPS from Thiobacillus ferrooxidans IFO 14262.

\begin{tabular}{lcc}
\hline & \multicolumn{2}{c}{ Amount of component } \\
\cline { 2 - 3 } Component & $\begin{array}{c}\text { Degraded polysaccharide } \\
(\mathrm{mg} / 100 \mathrm{mg} \text { of PS })\end{array}$ & $\begin{array}{c}\text { Lipid A } \\
(\mathrm{mg} / 100 \mathrm{mg} \text { of lipid A })\end{array}$ \\
\hline L-Acofriose & 13.2 & \\
L-Rhamnose & 29.7 & \\
D-Glucose & 32.0 & 9.8 \\
L-Glycero-D-manno-heptose & 1.1 & 54.7 \\
D-Glucosamine & 0 & $<0.01$ \\
Total fatty acids & 0 & \\
Phosphorus & $<0.01$ & \\
\hline
\end{tabular}

Analyses for fatty acids: Analysis of the total content of fatty acids, liberated by acidic hydrolysis from the LPS followed by methylation, revealed that 3hydroxymyristic acid is the main fatty acid component of the LPS. Small amounts of palmitic acid and oleic acid were also present (Table 2).

Degradation studies: Treatment of the LPS with mild acid $(1 \%$ acetic acid, $100^{\circ} \mathrm{C}$ for $2 \mathrm{~h}$ ) resulted in a separation of the water-insoluble lipid $\mathrm{A}$ and the watersoluble polysaccharide moiety, "degraded polysaccharide." The degraded polysaccharide fraction was subjected to gel chromatography.

The main sugar of the lipid A was glucosamine. The "degraded polysaccharide" contained L-acofriose, L-rhamnose, and D-glucose in the same ratio as those of the LPS (Table 4). 


\section{DISCUSSION}

The isolation and identification of LPSs from four strains of iron-oxidizing bacteria are reported. Besides major neutral sugars, heptose(s), KDO, and glucosamine were found in these LPSs. These are known to be regular sugar constituents of the core region and $\beta$-1,6-glucosamine disaccharide backbone of lipid $\mathrm{A}$ of gram-negative bacterial LPS. Lack of phosphorus among these LPSs is a remarkable feature.

The sugar composition of the LPS of $T$. ferrooxidans strain $\mathrm{R}_{2}(11)$ was reported to be different from those of the $T$. ferrooxidans strains described here. However, we have recently found the chemical composition of the LPSs from strains IFO 14262 and $R_{2}$ are very similar (27).

Vestal et al. (2) and HiRT and Vestal (3) have shown that cultural conditions and choice of energy source influence the yield and composition of the LPS of $T$. ferrooxidans strain TM. We found that the LPSs of T. ferrooxidans IFO 14246 and IFO 14262 from cells grown on ferrous sulfate and elemental sulfur did not differ in their content of neutral sugars and fatty acids and in their migration pattern on SDS-PAGE.

The LPS from $T$. ferrooxidans IFO 14262 was investigated in more detail. In addition to L-rhamnose, D-glucose, D-glucosamine, L-glycero-D-manno-heptose, and KDO, L-acofriose was found in this LPS. L-Acofriose has been reported in the LPSs from Klebsiella K73:010(28), Rhodopseudomonas capsulata 37b4(29), Rhodopseudomonas rubrum 2.4.6.(30), but has not previously been reported in Thiobacillus. Since L-acofriose represents $12.7 \%$ of the LPS dry weight in the $T$. ferrooxidans strain, it seems to be present in repeating units of the polysaccharide moiety, as in the case of Anabaena variabilis (31). As the proportion of Lacofriose/L-rhamnose/D-glucose in the degraded polysaccharide from the LPS is about $1: 2: 2$, the simplest repeating unit conceivable would contain a minimum of five sugar residues. Presumably KDO mediates the connection between lipid A and the polysaccharide in the LPSs of $T$. ferrooxidans.

The presence of sugar O-methyl ethers as characteristic constituents of the $\mathrm{O}$ specific chains in the LPSs of photosynthetic bacteria (29) and chemolithotrophic bacteria Nitrobacter hamburgensis (32) and T. ferrooxidans IFO 14262 may suggest a possible genealogical relation between photosynthetic bacteria and chemolithotrophic bacteria. The LPSs of other iron-oxidizing bacteria, such as L. ferrooxidans IFO 14244, T. ferrooxidans IFO 14245 and IFO 14246, do not contain L-acofriose.

Since glucosamine was found in the lipid A, it may be assumed that the lipid A of $T$. ferrooxidans has a backbone of glucosamine units, similar to that of Enterobacteriaceae. The main fatty acid of the $T$. ferrooxidans IFO 14262 LPS is 3hydroxymyristic acid, as generally found in lipid A of other LPSs as well.

Recent studies (27) on the composition of lipid A and core regions of the LPSs of Thiobacillus strains revealed that those from two strains of $T$. ferrooxidans and one strain of $T$. thiooxidans have glucosamine and 2,3-diamino-2,3-dideoxyglucose 
as a lipid A backbone and that those from T. novellus and Thiobacillus sp. IFO 14570 contain 2,3-diamino-2,3-dideoxy-glucose in their lipid A. It would be of interest for phylogenetic reasons (33) to investigate the core region and the lipid A constituents of the LPSs of iron-oxidizing bacteria in more detail.

We wish to thank Dr. A. P. Harrison Jr., Professor of Missouri University, U.S.A., for providing us bacterial strains and for his valuable suggestions. We also thank Mr. H. Takeda, Chemical Research Laboratories of Takeda Chemical Industries, for his excellent mass spectrometry analysis and valuable suggestions. We are grateful to Dr. H. Mayer, Max-Planck-Institut für Immunbiologie (F.R.G.), for his criticism of the manuscript. Grateful acknowledgement is also made to Dr. T. Iijima, Director of this Institute, for his encouragement and valuable discussions.

\section{REFERENCES}

1) W. S. WAng, M. S. Korczynski, and D. G. Lundgren, J. Bacteriol., 104, 556 (1970).

2) J. R. Vestal, D. G. Lundgren, and K. C. Milner, Can. J. Microbiol., 19, 1335 (1973).

3) W. E. Hirt and J. R. Vestal, J. Bacteriol., 123, 642 (1975).

4) A. P. Harrison, Jr., Int. J. Syst. Bacteriol., 31, 327 (1981).

5) D. B. Johnson and W. I. Kelso, J. Gen. Microbiol., 129, 2969 (1983).

6) R. Guay and M. Silver, Can. J. Microbiol., 21, 281 (1975).

7) G. J. M. W. Arkesteyn and J. A. M. de Bont, Can. J. Microbiol., 26, 1057 (1980).

8) A. P. Harrison, Jr., B. W. Jarris, and J. L. Johnson, J. Bacteriol., 143, 448 (1980).

9) A. P. Harrison, Jr., Int. J. Syst. Bacteriol., 33, 211 (1983).

10) A. P. Harrison, Jr., Annu. Rev. Microbiol., 38, 265 (1984).

11) M. Rodriguez, S. Campos, and B. Gomez-Silva, Biotech. Appl. Biochem., 8, 292 (1986).

12) A. P. Harrison, Jr., Arch. Microbiol., 131, 68 (1982).

13) O. WestPhal and K. JANN, In Methods in Carbohydrate Chemistry, Vol. 5, ed. by R. L. WhistLeR, Academic Press, New York (1965), p. 83.

14) H. Mikami and Y. Ishida, Bunseki Kagaku, 32, E207 (1983).

15) J. S. Sawadecker, J. H. Sloneker, and A. Jeanes, Anal. Chem., 37, 1602 (1967).

16) A. Weissbach and J. Hurwitz, J. Biol. Chem., 234, 705 (1959).

17) P. S. Chen, T. Y. Toribara, and H. Warner, Anal. Chem., 28, 1756 (1956).

18) S. Allen, T. G. Bonner, E. J. Bourne, and N. M. Saville, Chem. Ind., 630 (1958).

19) U. K. Lammli, Nature, 227, 680 (1970).

20) C. M. Tsai and C. E. Frasch, Anal. Biochem., 119, 115 (1982).

21) K. Imai, M. Takeuchi, and I. Banno, Curr. Microbiol., 11, 281 (1984).

22) H. Buorndal, C. G. Hellerquist, B. Lindberg, and S. Svensson, Angew. Chem. Int. Ed., 9, 610 (1970).

23) B. Lindberg, In Methods in Enzymology, Vol. 28, ed. by V. Ginsburg, Academic Press, New York (1972), p. 178.

24) V. Pozsgay and P. Nanasi, Carbohydr. Res., 81, 184 (1980).

25) H. Muhr, A. Hunger, and T. Reichstein, Helv. Chim. Acta, 37, 403 (1954).

26) I. M. Harrison, R. Young, M. B. Perry, and G. A. Adams, Can. J. Chem., 45, 1987 (1967).

27) H. Bjorndal, B. Lindberg, W. Nimmich, Acta Chem. Scand., 24, 3414 (1970).

28) A. Yokota, M. Rodriguez, Y. Yamada, K. Imai, D. Borowiak, and H. Mayer, Arch. Microbiol., 149, 106 (1987).

29) J. Weckesser, G. Drews, and H. Mayer, Annu. Rev. Microbiol., 33, 215 (1979).

30) J. Weckesser, H. Mayer, and G. Drews, Eur. J. Biochem., 16, 158 (1970).

31) J. Weckesser, A. Katz, G. Drews, H. Mayer, and I. Fromme, J. Bacteriol., 120, 672 (1974).

32) H. MAYER, E. Bock, and J. WeCKeSSER, FEMS Microbiol. Lett., 17, 93 (1983). 
33) H. MAyer and J. Weckesser, In Handbook of Endotoxin, Vol. 1, ed. by E. Th. Rietschel, Elsevier, Amsterdam, New York, Oxford (1984), p. 221.

34) L. D. Kennedy, Carbohydr. Res., 87, 156 (1980).

35) S. Sakuma, S. Kawanishi, and J. ShoJi, Shoyakugaku Zasshi, 22, 23 (1968) (in Japanese). 